\title{
CONTEMPORARY COMMENTATORS ON J.S. MILL'S ACCOUNT OF WOMEN'S SOCIO-POLITICAL ISSUES
}

\author{
COMENTADORES CONTEMPORÂNEOS DA ABORDAGEM MILLIANA \\ DAS QUESTÕES SÓCIO-POLÍTICAS REFERENTES ÀS MULHERES
}

\author{
ÁTILA AMARAL BRILHANTE \\ (Universidade Federal Ceará, Brasil) \\ FRANSCISCO JOSÉ SALES ROCHA \\ (Universidade Federal Ceará, Brasil)
}

\begin{abstract}
RESUMO
Este artigo objetiva mostrar que a maioria dos comentadores contemporâneos de J.S. Mill falham por não situar a abordagem que ele fez das questões referentes às mulheres no contexto mais geral do pensamento político dele. Em razão disso, eles não percebem que J.S. Mill defendeu mudanças institucionais para permitir que as mulheres votassem e que as que fossem casadas tivessem o direito à propriedade e o acesso à educação superior, a fim de que o casamento passasse a ser um relacionamento entre iguais fundado na amizade e na cooperação. Isto tornaria as famílias o lugar principal da educação para a cidadania e renovaria a sociedade maximizando o conjunto de recursos intelectuais disponíveis com a participação das mulheres na vida pública e as tornando diretamente responsáveis diante da sociedade por suas escolhas. Logo, accountability está no cerne da preocupações de J.S. Mill com as questões sócio-políticas concernentes às mulheres.
\end{abstract}

Palavras-chave: J.S. Mill. Voto feminino. Accountability. Autonomia.

\begin{abstract}
This article is purported to show that most of J.S. Mill's contemporary commentators failed to situate his account of women's issues in the broder context of his political thought. In view of this, they did not see the fact that Mill supported institutional changes in order to enfranchise women and allow married women to own property and benefit from higher education, on the grounds that such changes were important in transforming marriage into a relationship between equals based on friendship and cooperation. This would cause families to become the main locus of education for citizenship and renew societies by maximizing the poll of intelectual resources available with women in public life and render them directly resposible for their choice before society. Thus, accountability is at the haert of Mill's account of women's socio-political issues.
\end{abstract}

Key-words: J.S. Mill. Women voting. Accountability. Autonomy.

\section{Introduction}

In this article, it will be shown that accountability is a central concern of J.S. Mill's (hearafter referred to as Mill) views on women's issues, especially in the way they are 
presented in Subjection of Women, a book he wrote in 1861, but that was not published until 1869. In it, Mill argued in favour of the recognition of the legal and moral personhood of women. He judged it essential both to make government accountable to women and to make women accountable before society for their choices and opinions on public matters. It will be contended that Mill claimed that acknowledging men and women as partakers of a common dignity was vital in bolstering cooperation in modern societies which required increasing interdependency among their members. This work is devoted to analyse the acuracy of the most important contemporary commentators of Mill on women's issues. It is important to keep in mind that from now on The Collected Works of John Stuart Mill, J. M. Robson and others (eds.), 33 vols., (Toronto and London: University of Toronto Press and Routledge \& Keagan Paul, 1963-1999) will be referred to as $C W$ followed by the numbers of the volumes in which each work is inserted and the numbers of the pages. In addition to this, it is important to pay attention to the fact that the collection of articles entitled John Stuart Mill's Social and Political Thought: Critical Assessments edited by Smith, G.W, 4 vols., (London: Routledge, 1998) will be referred to as $C A$ preceded by the title of the article and followed by the indication of the volume in which the article is inserted in the collection and by the numbers of the pages. This is due to the fact that most of the articles of the Mill's commentators on the topic at issue are part of the collection mentioned.

The second section will describe the main arguments of some of the most important contemporary commentators on Mill's account of women's issues, and show how these commentators related these issues to other aspects of his political philosophy. At the heart of this section are the following questions: 1) Did Mill advocate women's enfranchisement only to remove legal disabilities, or did he see it as a means of bringing about wider socio-cultural changes? 2) Did he think the differences between men and women were caused by culture rather than by nature? 3) Did he favour the idea that the marriage contract should be grounded on partnership? Special attention will be paid to Susan Mendus' contribution to this topic because she argues that Mill's account of women's issues dovetails with his praise of diversity and his intention of making government accountable to the people.

The third section will demonstrate that most commentators have failed to situate Mill's views on women's issues in the broader context of his thought. This has not prevented commentators from grasping certain elements of Mill's account. However, it will be argued that most of them fail to recognise the extent to which Mill's concern with accountability influenced his account of women's enfranchisement, and fail to perceive that he promoted the 
recognition of women's legal personhood because this would allow them to participate in the public sphere, develop their sense of responsibility, and increase co-operation amongst all members of society.

The fourth section will argue that Mill believed that the regeneration of society depended to a significant extent on the recognition of women as autonomous human beings. He regarded this recognition as a matter of justice,. Mill wanted to transform marriage into a relationship between equals, on the grounds that this would convert families into schools of co-operation and friendship. It will be further argued that Mill ultimately intended to render all citizens who acted in the public sphere accountable for their choices.

\section{Commentators on mill on women's issues}

Julia Annas argues that Mill developed an inconsistent account of sexual inequality in Subjection of Women (see ANNAS, 'Mill and the Subjection of Women', CA, v. 4, p. 245). For Annas, there are two strands of argument that can be adopted in order to oppose sexual inequalities: the reformist and the radical. The reformist holds that the legal system needs to be reformed in order to give women opportunities without which their desires and needs will be frustrated. This argument is utilitarian because it assumes that, by putting women's dormant abilities to work, everyone will benefit. For Annas, this approach is compatible with many of the historically established differences between the sexes: 'all that it excludes is that these differences should justify inferior opportunities for women in the respects in which their contribution can be recognized'(ibid., p. 232). In contrast to the reformist approach, the radical approach holds that there are no relevant differences between men and women that can justify any institutionalization of sexual differences (see ibid., p. 233). For Annas, Mill's case for women's liberation in Subjection of Women mixed

the reformist and the radical accounts. On the one hand, Mill followed the radical approach, saying that patriarchy was a mere consequence of women's comparative physical weakness, that both sexes could compete on an equal basis, and that women only failed to express their dissatisfaction with marriage more often than they did due to the submissiveness inculcated by the education they received. On the other hand, Mill followed the reformist approach in stating that women had a bent for the practical, while men had a bent for abstract reasoning, that despite being more flexible women's minds were unable to sustain the same level of intellectual effort as men's because men had larger brains, and that women's peculiar aptitudes were destined merely to complement men's abilities. Besides, Annas thinks that 
Subjection of Women lacks the clarity found in Enfranchisement of Women (1851), the book his wife Harriet Taylor wrote to summarises her pivotal ideas about the social consequences of women's disfranchisement, regarding the need for women to earn a living in order to achieve equal standing with men (see ibid., 244). For Annas, when the defence of women's emancipation is grounded on complementarity and not on equality, the result is the recognition that women can be good companions for men, but never that men can be good companions for women. Overall, Annas believes that Subjection of Women does not do justice to the topic it addresses.

Mary Lyndon Shanley argues that Mill's contemporary critics failed to realise that he criticized the corruption of male-female relationships from the point of view of 'the normative assumption that human relationships between equals were of a higher, more enriching order than those between unequals' (SHANLEY, 'Marital Slavery and Friendship: John Stuart Mill's The Subjection of Women', CA, v. 4, p. 258). Thus, inequality was not compatible with genuine friendship because it did not imply mutual respect, but rather subordination, which was a hindrance to people's improvement (see ibid., 258). Personal enhancement can only occur in an atmosphere of reciprocity. This is why Mill wanted marriage to be a locus of mutual sympathy and undestanding (see ibid., p. 248). Shanley argues that Mill saw the social situation of married women at that time as a form of slavery because their personalities were subsumed to those of their husbands. Working-class women were prevented from receiving due compensation for their work, while middle and upper-class women were barred from higher education. A woman was deprived of the power of 'controlling' her 'earnings', of 'entering contracts', and of defending her bodily autonomy by resisting unwanted sexual relations'( see ibid., p. 251). Shanley claims that, for Mill, inequality between spouses was the root of social disorder (see ibid., p. 253). She argues that Mill's critics also failed to grasp that his commitment to equality in marriage was a moral imperative, and that his acceptance of the then existing sexual division of labour was a practical matter (See ibid., p. 257-8). Mill favoured domestic arrangements whereby men and women moved in different spheres of activity because such was most appropriate for the then existing circumstances (see ibid., 258). In Shanley's view, Mill never agreed with those amongst his contemporaries who believed in a natural and inevitable complementariness between women and men. She contends, however, that he advocated a sort of dynamic complementariness in which roles would be determined according to the characteristics of each couple. In addition to this, Shanley states that Mill advocated not only changes in legislation, but also a re-education of 
the passions, as essential measures to promote the interests of the community. She assumes that Mill was unable to see the positive role that sex and shared parenting might play in marriage, but thinks that his view that the highest maculine and feminine characters were without any real distinction lent support to the idea that there was a basic equality within the human family (see ibid., p. 256).

Elaine Spitz criticises Shanley's interpretation of Subjection of Women, alleging that Shanley ignores the fact that Mill's principled opposition to telling people what they ought to do prevented him from proposing shared parenting (see SPITZ, 'On Shanley Marital Slavery and Friendship', $C A$, v. 4, pp. 265-6). According to Spitz, since Mill was not a deontological moralist, he could not be expected to pronounce on the best way for people to behave. His feminism 'derives its force from the primacy it gives to liberty (which is always a negative version of freedom, requiring the removal of external obstacles)'(See ibid., p. 266). Spitz believes that Mill's main concerns in Subjection of Women were to secure women's legal rights and their economic independence (see ibid., pp. 254-5). The lack of judicial rights and economic freedom denied women opportunity to pursue independently their own good. In Spitz's view, Mill wanted to free women from the imposition of social conformity, but did not intend to prescribe any specific plan of life for them. According to Spitz, Mill would oppose the attempt of some contemporary feminists to prescribe certain arrangements for marriage, because that would amount to an undue interference in other people's quest for their own conception of the good life.

Nadia Urbinati argues that Mill advocated a conception of individuality that was at odds with the view 'that reason is masculine and sentiment is feminine and the latter is inferior to the former' (URBINATI, 'John Stuart Mill on Androgyny and Ideal Marriage', $C A$, v. 4, p. 271). She believes that Mill and Harriet Taylor developed a notion of individuality that corresponded to the idea of 'l'Homme en general, l'Homme universel' of the SaintSimonians, which comprised both sexes and all races. For Urbinati, such a notion was at odds with the dichotomy between feminine and masculine, which entails hierarchy and domination. Urbinati presumes that, in breaking the rigid distinction between masculine and feminine, Mill intended to promote equality as a precondition of individual free choice and selfdetermination. Therefore, Mill favoured changes in marriage legislation and marriage customs because he did not want the domestic system to remain a school for tyranny, but a microsociety of equals which would raise humanity to a higher condition (see ibid., p. 278). For Urbinati, Mill's critics exaggerate the importance which should be attached to the question of the internal coherence of Subjection of Women, and disregarded the relevance of 'the concrete 
support that Mill gave for the movement of social and political emancipation of women' (ibid., p. 281). She stresses that Mill did not expect married women to devote themselves solely to the management of a household because, for Mill, when labour was a means of selfrealisation, the decision to work was a matter of 'free choice and personal abilities; but when it is a necessity, women cannot be compelled by their husbands to work both inside and outside their houses because this is an unjustified form of exploitation' (ibid., p. 282). So, for Urbinati, the restriction Mill placed on women's participation in the labour market was a way of preventing exploitation.

Susan Mendus claims that Subjection of Women coheres with the general thrust of Mill's political writings, and she rejects the reason-emotion dichotomy. She argues that Subjection of Women 'draws much of its persuasive power from the doctrines advanced in Harriet Taylor's Enfranchisement of Women' (MENDUS, 'John Stuart Mill and Harriet Taylor on Women and Mariage', CA, v.4., p. 312-23). Mendus sees Subjection of Women as a political essay which "was timed to coincide with the growing parliamentary and political movement for the reform of the franchise and, especially, with the campaign for votes for women' (ibid., p. 313). However, the central concern of Mill's book was not to promote legal reform, but to remove inequalities that hindered the moral improvement of mankind:

\footnotetext{
Again and again in these texts we find indications that John Stuart Mill and Harriet Taylor are urging, not legal improvement only, but a complete revision of the moral relationship between sexes. Their advocacy of legal alteration is subordinate to this and motivated by it (ibid., p. 317).
}

For Mendus, critics of Subjection of Women are wrong in seeing it as a mere catalogue of legal disabilities suffered by Victorian women. She argues that Subjection of Women is close to the tenets of present-day radical feminism. She points to two convergences between them. First, radical feminism holds that the existing patriarchal system pressures women to become sexual slaves by establishing their attractiveness to men as the most important criterion by which to evaluate them (see ibid., p. 318). Following an identical line of reasoning, both Mill and Harriet Taylor contended that women were brought up with the social expectation that they had no option other than to marry, and this guaranteed 'that in marriage a man will get not a forced slave but a willing one'. Second, radical feminists aim to transcend the supposed patriarchal dualism between reason and emotion. Mill also acknowledged emotion and rationality as two essential dimensions of human beings. For Mendus, Mill's intellectual partnership with Harriet Taylor was a successful one because they complemented each other. While Mill was basically a thinker, Harriet Taylor had intuitive 
insight and imagination. The claim of the contemporary radical feminist Shulamith Firestone for an emotional science is plainly consistent with Mill's praise of imagination as a necessary complement to intellect, and vice versa (see ibid., p. 322).

The liberal democratic tradition envisages a society where governments are accountable to, and social arrangements are framed so as to represent the interests of, all members of the community (see MENDUS, 'Losing the Faith: Feminism and Democracy' in DUNN (ed), 1995, p. 208). For Mendus, Mill played an important role in the history of liberalism by showing that, in excluding women from politics, liberal societies were at odds with their own principles. She counts Mill amongst those who believe that democratic societies are superior because they deliver unity out of diversity. Mill's conception of democracy was premised on the idea that people were not indistinguishably alike, and because of this, equality had to be pursued through the recognition of difference, otherwise society would degenerate into imposed uniformity (see ibid., p.217). According to Mendus, in Subjection of Women, Mill tried to show that women should not be confined to domestic concerns because this represented an improper limitation on the exercise of their abilities and was, as such, detrimental to society. She thinks that Mill wanted to reform the institutions of Victorian Britain to meet the claims of justice generated by the liberal democratic conscience, and amongst these claims the emancipation of women figured prominently.

\section{Mill, women's issues, and liberalism}

Julia Annas fails to perceive that Mill saw what she calls the reformist and radical approaches to feminism as two sides of the same coin. He advocated reforms in the legal system in an attempt to change a society that educated women for submission. In the first chapter of Subjection of Women, Mill claimed that the submission of women was not based on reason or nature, but was a consequence of education. Besides, he affirmed that the then existing system of inequality was unacceptable. Annas's view that Mill's conception of complementarity between men and women undermined his radical credentials is not correct. The differences between women and men that Mill referred to in Subjection of Women are not presented as natural properties. He clearly stated that such differences were related to capacities that appeared more frequently either in men or in women, and were very likely to be associated with the activities they performed and the education they received. This was why he thought a proper understanding of these differences would be possible only when men and women had had the same education. In fact, he argued that spouses with different 
capabilities should use these capabilities to promote a dynamic complementarity, and not to legitimate oppression. Hence, marriage should be a voluntary association in which the role of the members was defined according to the aptitudes of each couple. One could not assume, as Annas does, that Mill's notion of complementarity amounts to subjection for wives. Annas's statement that, in Subjection of Women, Mill was less emphatic in defending the need for women to earn a living in order to achieve an equality of standing with men than Harriet Taylor was in Enfranchisement of Women is correct. Mill's earlier essay On Marriage (183233?) likewise paid more attention to this issue than Subjection of Women. In Subjection of Women, he certainly continued to advocate the participation of women in political decisionmaking and in the labour market. However, these questions were addressed in Subjection of Womem in the light of broader philosophical and political concerns. For Mill, female emancipation was a matter of justice because 'the system of male domination of females violates a basic principle of justice - reward and advantage are based on birth, not merit or personal exertion' (BERGER, 1984, p. 197). But he presumed that, by participating in the suffrage, women would contribute to a major transformation in society that would allow the emergence of a new pattern in the relationship between the sexes (see ibid., p. 202). Mill was not merely interested in discussing the legal disabilities of women, but in creating the conditions for them to be autonomous human beings. His persistent affirmation that the form of marriage existing at that time was at odds with modernity dovetails with his theory of history. As has already been shown, Mill believed that society was evolving towards the removal of social inequalities, a process that was undermining individuality (see BRILHANTE, 2009, pp. 102-4). It was thus essential to remove such inequalities, because they discouraged social cooperation on which modern societies increasingly depended by weakening people's sympathetic feelings towards other members of society (see ibid., pp. 160-62). Besides, in societies in which people's social roles are not inexorably tied to their situation of birth, inequalities that undermined individuality were not accepted. So, as Mill thought that the very dynamic of modern society tended to make the existing form of the marriage relationship indefensible, he decided to advocate changes in legislation, which he saw as instrumental in unleashing the more comprehensive changes that he aimed at. He avoided drawing attention to these wider changes because they would attract opposition from those who wanted to keep things as they were. In Subjection of Women, Mill combined his philosophical views on women's issues with his political aim of promoting women's 
participation in the voting process. This combination can be clearly seen in his speech of 17 July 1869 to the Gallery of the Architectural Society:

The suffrage, while it is the road to other progress, commits no one as to what other things progress consists of. Let us but gain the suffrage, and whatever is desirable for women must ultimately follow, without its being necessary at present to decide, or indeed possible to foresee, all that is desirable. The mere fact of claiming the suffrage is giving an impulse, such as never has been given before, to all proposals for doing away with injustice to women. ( $C W$, v.29, p. 373).

Shanley correctly argues that some of Mill's critics fail to realize that his defence of changes in legislation was not an end in itself, but a means to promote the re-education of the passions that could transform marriage into a relationship of friendship between equals. She is also accurate to say that Mill advocated a dynamic kind of complementariness between spouses, and not one in which the roles were fixed. Shanley clearly perceives that Mill was not a timid reformer, but a fierce supporter of women's full moral and legal personhood at a time when they were both denied, and that he was fully conscious that the law was only one of the factors that moulded individuals' characters (see MORALES, 1996, pp. 7,51). Nevertheless, she gives an incomplete explanation of Mill's acceptance of traditional domestic arrangements and his incapacity to see the positive role that sex and shared parenting might play in marriage. Mill affirmed that, in some circumstances, the traditional family arrangement in which the wife supervised the domestic expenditure and the husband earned the income was the most suitable. But this affirmation should not be interpreted merely as an attempt to make his opinion more acceptable to his contemporaries ( $C W$, v. 21, p. 297). He believed that a woman was of more value in the eyes of the man who was legally her master when she contributed with her income to the maintenance of the household. However, as she was legally under his tutelage, and since her husband was the one who had the power to decide if and where she should work, the risks of abuse were immense. For example, the husband could force his wife to work, and leave 'the support of the family to her exertions, while he spends most of his time in drinking and idleness'(ibid., p. 298). Therefore, in conceding the value of the traditional marriage arrangement in this situation, Mill's main concern was to prevent women from being victims of what he deemed additional exploitation. Even though Mill believed that the spirit of the age was unequivocally on the side of those proposing changes in the legal and social condition of women, he knew that such changes would not occur immediately (see $C W$, v.29, p. 375). His priority was, therefore, to campaign for women's enfranchisement, access to higher education, and for married women's rights to own property. He believed that these reforms could break the legal inferiority that was at the 
root of women's subjection, and supposed that, once legal inferiority was eliminated, the dynamic of society would tend to favour equality in marriage relationships even more strongly. His acceptance of traditional marriage arrangements was also a realistic recognition that the wide-scale participation of women in outdoor occupations would not occur immediately. Besides, he knew that some couples would see traditional domestic arrangements as ideal, even in a situation in which women's legal tutelage no longer existed. Mill did not believe that many couples would take this view, but felt, nonetheless, that he should respect those who did make that choice. As a matter of fact, Mill thought that once equality was an established principle, it was up to couples themselves to adjust their marriage arrangements accordingly (see $C W$, v.21, p. 298).

It is necessary to comment further on Shanley's assertion that Mill failed to see that sex and shared parenting might play a positive role in marriage. The conditions of the nineteenth-century working classes were appalling. The Ten Hours Act of 1847 limited the working hours for women and young persons under 18 to ten hours per day, but it was still possible for men to be working for twelve hours per day (see MURPHY and others, 1999, p. 191). The Factory Act of 1850 reduced Saturday working for women and children and established breaks for meals. These two pieces of legislation were restricted to textile factories until 1867, when they gained general application. It seems reasonable to infer that, despite recognizing that men were becoming increasingly domestically-minded, Mill realized that shared parenting would not be seen as an appealing activity for those who already worked twelve hours a day, and were educated to see the bringing up of the family as the first call upon women's exertions. But the idea of shared parenting is compatible with Mill's notion of marriage as a voluntary association in which the roles of its members were defined by agreement. He neither opposed the involvement of men in the bringing up of the family, nor the involvement of women in public affairs, because both situations made marriage relationships more meaningful by creating common ground between the spouses, an effect which Mill deemed to be positive for society.

In relation to Shanley's belief that Mill failed to see that sex might play an important role in marriage, it is important to consider what follows. From early in his thought, Mill criticized the fact that the law of marriage was designed to keep relationships based solely on sexual attraction (see $C W$, v. 21, p. 40). He ranked intellectual pleasures higher than physical ones, but it is not correct to infer from this that he paid no attention to the importance of sex in the marriage relationship or regarded it as irrelevant to general happiness. Mill did not 
provide a detailed account of sexuality in marriage relationships because he believed that this issue was related to people's private sphere of conduct which should be protected from interference from state and society (see $C W$, v. 18. p. 226). In view of the intimacy of sexual relations, Mill did not put forward general prescriptions about the role sex might have in married life, but presumed that each couple should be left to define that role for themselves.

Elaine Spitz is correct to criticise some contemporary feminists who do not realise that Mill would have opposed attempts to prescribe certain arrangements for marriage because such prescription would amount to an undue interference in other people's quest for their own conception of the good life. She is also correct to assert that Mill's main concern in Subjection of Women was to guarantee legal rights for women that would enable them to act as responsible moral agents. But it is important to keep in mind that Mill saw in his relationship with Harriet Taylor a paradigm of the marriage relationship. In his view, marriage was a sort of debating society between couples that was likely to be successful only amongst those whose natures were congenial and who could therefore develop a deep friendship. He did not intend to impose such an ideal of marriage on others, but thought that this was the sort of relationship that would prevail when the principle of equality became a reality in marriage. Besides, he hoped that, when co-operation and the sharing of experiences was the principle governing the relashionship between married couples and his children, family life would become a preparation for citizenship (see JONES, 2000, p. 101). Mill envisioned a democratic society in which families educated their members for freedom. That is, for Mill, selfgovernment was a practice to be promoted not only in political and labour relations, but within families as well (see BAUM, 2000, p. 262-3). Mill intended to promote mutual respect among couples. This could happen only when there was an acceptance that both men and women were autonomous human beings. He assumed that society would change in a positive direction when families recognised the need of such an acceptance. The predominance of relationships based on self-respect and respect for others would be essential in creating the atmosphere of co-operation and friendship that would lead to the improvement of society. Mill thought that the perpetuation of abuses of power was detrimental both to those who performed them and to those who suffered their consequences. He agreed with Plato's idea that the tyrant's life was impoverished because he could not have genuine friends, but only flatterers. Friendship presupposed a recognition that dignity could not exist in the context of relations of submission. This is why Mill adopted William Thompson's idea that the command-obedience ethic should not prevail in marriage relatonships. Thompson wrote a book on behalf of women against the passage in James Mill's Essay on Government, which 
defended women's exclusion from the suffrage. Thompson influenced Mill whom he met in the early part of 1825 in the Co-operative Society (see $C W$, v. 1, p. 129). Hence, it is correct to assert that, for Mill, inequality between men and women is inimical to moral progress and to social improvement. This is why he exhorted men to change the selfish pleasures of the despot for the sympathetic pleasures of the friend (see MORALES, 1996, p. 147).

Urbinati's account has the merit of recognising: 1) that Mill wanted the domestic system to be a micro-society of equals, which he deemed essential to raise humanity to a higher condition; 2) that he accepted traditional domestic arrangements, because he feared the possibility of women being compelled by their husbands to find outdoor occupations; and 3) that some of Mill's critics disregard the relevance of his support for the movement for political emancipation. However, Urbinati's view that Mill and Harriet Taylor adopted a conception of individuality that corresponded to the idea of 'l'Homme en general' and blurred distinctions between masculine and feminine needs to be challenged. Urbinati's claim that Mill believed that there was no relation between 'masculine' and 'feminine', on the one hand, and biological sexuality on the other, seems to go beyond Mill's own position. Despite believing that many of the so-called natural differences between men and women were consequences of education, he regarded the relation between 'masculine' and 'feminine' on the one hand, and biological sexuality on the other, as a topic that had yet to be clarified. One should avoid attributing conclusions to Mill that he had not reached. He thought that both men and women should be autonomous individuals, in other words that they should be empowered to consider their commitments and to make genuine choices (see DONNER, W. 'John Stuart Mill's Liberal Feminism', in EISENACH (ed), 1999, p. 135). Mill's defence of equality between the sexes was grounded on the idea that character must derive from one's inner being, and should not be imposed from without (see ibid., p. 136). He believed that under the regime of equality it would be easier to estimate the differences between women and men, because both would have the opportunity to exercise their capabilities. When Mill referred to women's bent for the practical and ability to sympathise with public concerns, and men's bent for abstract reasoning and ability to undertake sustained intellectual effort, he presumed that certain characteristics were more present in one sex than in the other. However, admitted that there was no basis available to establish with precision if they were merely cultural products, so that only more or less probable conjectures could be made about this subject (see $C W$, v.21, pp. 277-8, 304-5). Urbinati's claim that Mill's conception of individuality is marked by an androgenous ideal seems groundless, because, for Mill, autonomy essentially required self- 
determination and did not preclude difference. Hence, Mill's intention to ground family life on friendship did not entail an androgenous ideal according to which differences were irrelevant. Mill was cautious in his analysis of the differences between men and women, and this impeded him from adopting a reductionist account of women's subjection, such as the one Engels presented in Origin of the Family, Private Property, and the State. Engels accepted the evolutionary scheme of Lewis H. Morgan, according to which the monogamous family system dominated by male authority was the last stage of a process that began with promiscuity, and was followed by group marriage and polygamy. Engels added to Morgan's account of familial relations the idea that monogamy enforced by law was a device to perpetuate the private property system which was the ultimate cause of women's subjection. To underpin this claim, Engels alleged that familial relations before stable monogamy were matrilineal (see ENGELS, 1953, v. 3, pp. 51-63). Mill believed that the subjection of women was not a by-product of capitalism but a reality grounded in deep-rooted feelings and emotions which were present in various modes of production and stages of history. He saw the social trend of his time as one that did not favour the permanence of women's subjection, but favoured their integration in social affairs. Nonetheless, he rejected the idea of converting claims about differences between men and women based on empirically verifiable generalizations into normative conclusions about women's and men's inequality. Therefore, he believed it was unacceptable to legimate women's subjection to men on the grounds that women were inferior in muscular stregth (see MORALES, 1996, p. 162). Mill observed that what many deemed to be natural characteristics of men, such as starved emotional constitutions and overbearingness, were in reality socially determined traits. Hence, the normal should not be equated with the correct.

Susan Mendus correctly recognises that Subjection of Women coheres with the general thrust of Mill's political writings, and that in it Mill advocated the removal of inequalities that compromised autonomy and hindered the moral improvement of individuals. She was also correct in stating that Mill recognised that women were willing slaves because the social expectation for them to get married was very strong, and they were educated to think that marriage was their only path to happiness. In addition, Mendus has the merit of realising that Mill pursued equality through the recognition of characteristics that distinguished women from men. The notion of equality referred to here implied the recognition that both men and women were capable of making genuine choices based on their own conception of the good life. Therefore, paternalism and subjugation were not capable of underpinning relations between men and women, because both partook of the same human nature and should be 
responsible for their choices. Mill thought that rather than precluding diferences of tastes and opinions between men and women, equality would demand them. In order to understand this one should pay attention to the concept of individuality outlined in On Liberty. There, Mill portrayed the autonomous individual as being capable of deviating from the dominant values of society and of searching for experiments of life that fulfilled the demands of his or her uniqueness. The more an individual was able to identify the set of experiments that enhanced his or her inward potentialities, the more able he or she was to make genuine choices which corresponded to his or her deeper aspirations. Mill saw autonomous individuals not only as choice-makers, but also as engaged reasoners who scrutinised alternative ways of life in order to identify the one that suited them best (see $C W$, v.18, pp. 261-275). In view of all this, it is correct to assert that, for Mill, mental, physical, and social differences amongst human beings of both genders were not detrimental to society when they were consistent with relations based on mutual respect, but were objectionable when they entailed subjugation or paternalism. Mendus recognizes that Mill fought for changes in social relations, on the grounds that liberal democracies had allowed members of society to choose those who governed them and make government accountable to citizens. Mill also grounded women's enfranchisement on the fact that they needed it as a means of self-defence, so that their interests would not be ignored. In Subjection of Women, Mill was concerned to defend women's right to a voice in political matters, and to protect them from being victims of men's despotical power. He presented divorce as a way of impeding the complete assimilation of the wife to the slave. Mill did not treat the question of divorce extensively in Subjection of Women, but he had already written in favour of divorce in previous works, despite admitting that the indissolubility of marriage had contributed in the past to the elevation of the social position of women (see $C W$, v. 21, p. 40). He wanted the legislator to take worst-case scenarios into account, instead of assuming that men would always exercise power benevolently. Mill called the attention of legislators to the fact that marriage was not an institution designed for a selected group, and that women should be protected because 'men are not required, as a preliminary to the marriage ceremony, to prove by testimonials that they are fit to be trusted with the exercise of absolute power' ( $C W, \mathrm{v} .18, \mathrm{pp} .287)$. But he also claimed that women's ability to sympathise with public causes and to fraternise with other people would make their participation in the electoral process advantageous to society. In recognizing women as autonomous human beings, Mill upheld their right to have a voice in the administration of society and to be responsible for their own opinions and points of view. 
He wanted to change the existing situation in which women suffered the consequences of decisions made by governments, but in which representatives in parliament were neither chosen by nor accountable to them (see ibid., p. 290).

Mill's concern with accountability was present in everything he wrote concerning the social situation of of women. In On Marriage (1832-33?), he pointed to economic independence as a means of creating a balance of power within families and of making marriage a relationship based upon the wishes of both parties, thereby destroying the unchecked power of husbands. In Papers on Women's Rights (1847-50), enfranchisement was presented as a way of freeing women from a form of oppression that confined them to the domestic sphere and left them unprotected. In Subjection of Women, Mill refined his concern with accountability by taking into account all the aspects he had previously considered and placing them in the context of a broader theory of social and personal improvement. In his later speeches on women's enfranchisement, accountability clearly appeared as the foremost concern. In the speech of 17 July 1869 at the Gallery of the Architectural Society mentioned above, Mill argued that the enfranchisement of women was a democratic demand attuned to the spirit of the age because it allowed them to have 'a voice in choosing the persons by whom the laws are made and administered' ( $C W$, v. 29, pp. 374-375). In a speech delivered on 26 March 1870, at Hanover Square Rooms, Mill asserted that, if women had been enfranchised, Britain would not have had the Contagious Diseases Acts under which, in order to prevent the spreading of sexually transmitted diseases, daughters and wives of the poor are exposed to enforced medical inspection on the suspicion of a police-officer (see ibid., pp. 3889). Mill deplored the fact that those who introduced such Acts were not accountable to women, who had no say on their introduction, despite their drastic effect on them. He defended the repeal of the Contagious Diseases Acts, on the grounds that they condemned prostitutes to arbitrary medical inspections. Had women been properly represented, the Acts would not have been approved. Mill pointed to women's enfranchisement as a way of promoting among women 'a more cogent sense of their special duties as citizens, and of their general responsibilities as concerned with the advancement of the highest moral interests of the whole community' (see ibid., 391). In a speech given on 12 January 1871 in the Music Hall, Edinburgh, Mill commented on the fact that while wives were frequently the real prompter either of what men did well, or of what men did selfishly, they were not credited for what men did well nor held responsible for what they did selfishly (see ibid., pp. 404-5). He believed that women's power of cajolery was an undesirable form of influence because it rendered them unaccountable. For Mill, women should be enfranchised and made accountable 
for their choices, because power must be exerted with knowledge and responsibility (see ibid., p. 404). In view of all these considerations, it can be seen that Mill's concern with accountability was central to his writings on women's issues. This was a consequence of the central tenet of his political philosophy, according to which unchecked powers were always sources of corruption. He frequently related marriage to slavery because, in his opinion, masters and husbands exerted unchecked power over slaves and wives respectively. Therefore, in promoting equality and mutual consideration in marriage relationships, he was trying to maximize the happiness of society by doubling the number of people pursuing personal excellence (see SCARRE, 1996, pp.5-6). Mill failed to perceive that his overintellectualised relationship with Harriet Taylor could not be offered as a model for many people. The sort of attachments that exist between members of families are different from those existing between members of society at large, so that it is quite difficult to transform families into debating societies (see JONES, 2000, p. 102). Mill's concern with the issue of power within families was correctly focused, because families are powerful agencies in the formation of people's mentality, but he should have taken into account the fact that familial relations are situated primarily in the sphere of community (Gemeinschaft) and not in the sphere of society (Gesellschaft). In the sphere of Gemeinschaft, relations are marked by kinship, intimacy, cohesion, and continuity, while in the sphere of Gesellschaft relations are based on calculation, opposition, and pecuniary interest (NISBET, 1974, p. 11). But even if it is not feasible to tranform most families into debating societies, it is possible to improve mutual respect within them. Mill thought that the recognition of women's legal and moral personhood was essential to the implemention of his liberal ideals and to the improvement of women's treatment within their homes. Enfranchisement was an essential precondition if women were to be really represented and have the possibility of controlling those who governed. Their participation in the public sphere was thus a liberal ideal that Mill coherently advocated. The notion that the liberal differentiation between the private and public sphere implies the subjection of women is flatly wrong: the fact that the two spheres exist does not imply that women should be confined to one of them. Mill's concern with the enfranchiment of women was linked to his belief that an equilibrium of power between couples and within families could bring about benefits for society. Mill believed that advances in civilisation required people to rely increasingly on one another, and this would be possible only in a society where human beings saw themselves as partakers of a common nature and a common dignity. 


\section{Conclusion}

Mill believed that the regeneration of society depended to a significant extent on the liberation of women from the political and cultural obstacles to their recognition as autonomous human beings. He considered this recognition to be a matter of justice in that the existing system stamped the character of inferiority on women by disconsidering their merits and capabilities, and by leaving them unprotected from the tyranny of husbands in the sphere of the family. He supported institutional changes in order to enfranchise women and allow married women to own property and benefit from higher education, on the grounds that such changes were important in transforming marriage into a relationship between equals. $\mathrm{He}$ argued that families in which relationships were based on friendship and cooperation would be the main locus of education for citizenship in societies that were expected to have accountable governments. Mill presumed that the well-being of a society increased where women enjoyed liberty, because the enjoyment of such liberty minimized suffering and maximized the pool of available intellectual resources. He believed that women could introduce more altruism in the treatment of political matters and generate a renewal of social feeling, so as to make self-government a reality both in the family and in society. It was, therefore, necessary to promote an equilibrium of power within the family in order to promote the idea that human beings were partakers of a common dignity. This was important in modern societies whose members were becoming increasingly interdependent. Mill defended women's enfranchisement as a precondition for women to participate in the choice of representatives and to control those who governed them. But he also wanted them to be responsible for their own choices and points of view in public matters before society, because responsibility was correlative to autonomy. In short, everyone who had the power to make choices had to be held accountable for the consequences they bring about to community life. 


\section{References bibliography:}

BAUM, B. Re-reading Power and Freedom in John Stuart Mill. Toronto: Toronto University Press, 2000.

BERGER'S, F. R. Happiness, Justice and Freedom: The Moral and Political Philosophy of John Stuart Mill. Berkeley: University of California Press, 1984.

BRILHANTE, A.A. The Liberal-Utilitarian Conception of Democracy of John Stuart Mill: the centrality of accountability. Saarbrücken: VDM VERLAG-Dr. Müller, 2009.

DUNN, J (ed). Democracy: The Unfinished Journey 508 BC to AD 1993. Oxford: Oxford University Press, 1995.

EISENACH, E.J. (ed), Mill and the Moral Character of Liberalism. University Park: The Pennsylvania State University Press, 1999.

ENGELS, F. As Origens da Família da Propriedade e do Estado. In: Karl Marx and Friedrich Engels: obras escolhidas. São Paulo: Alfa-omega, 1953. v.3.

JONES,H.S. Victorian Political Thought. London: Macmillan, 2000.

MILL, John Stuart. Autobiography and Literary Essays. In: . $C W$. Toronto, London: University of Toronto Press, Routledge \& Keagan Paul. 1963-1999. v. 1.

. Later Letters, 1849-1873. In: $C W$. London: University of Toronto Press, Routledge \& Keagan Paul. 1963-1999. v. 14.

On Liberty. In: . $C W$. London: University of Toronto Press, Routledge \& $\overline{\text { Keagan Paul. 1963-1999. v. } 18 .}$

. Rationale of Representation. In: . $C W$. Toronto, London: University of Toronto Press, Routledge \& Keagan Paul. 1963-1999. v. 18.

. Thoughts on Parliamentary Reform. In: . $C W$. Toronto, London: University of Toronto Press, Routledge \& Keagan Paul. 1963-1999, v. 19.

Considerations on Representative Government. In: . $C W$. Toronto, London: University of Toronto Press, Routledge \& Keagan Paul. 1963-1999. v. 19.

J.S. Mill, Subjection of Women. In: .$C W$. Toronto, London: University of

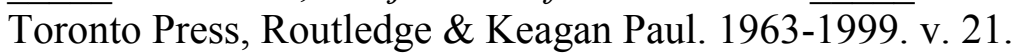


. J.S. Mill, On Marriage. In:

.CW. Toronto, London: University of Toronto Press, Routledge \& Keagan Paul. 1963-1999. v. 21.

. Public and Parliamentary Speeches July 1869 -March 1873. In:

London: University of Toronto Press, Routledge \& Keagan Paul. 1963-1999. v. 29.

MORALES, M. H. Perfect Equality: John Stuart Mill on Well-Constituted Communities. New York and Londom: Rowan \& Littlefield Publishers, 1996.

MURPHY, D and others. Britain 1815-1918. London: HarperCollins, 1999.

NISBET, R.A. The Social Philosopher. New York: Paladin, 1974.

SCARRE, G. Utilitarianism. London: Routledge, 1996.

SMITH, G.W (ed). John Stuart Mill's Social and Political Thought: Critical Assessments. London: Routledge, 1998, 4vols. 